\title{
"A synthesis of changing patterns in the demographic profiles of urban street vendors in Botswana, South Africa and Zimbabwe"
}

AUTHORS Gwendoline Vusumuzi Nani

ARTICLE INFO

DOI

RELEASED ON

JOURNAL

FOUNDER
Gwendoline Vusumuzi Nani (2016). A synthesis of changing patterns in the demographic profiles of urban street vendors in Botswana, South Africa and Zimbabwe. Problems and Perspectives in Management, 14(3-2), 549-555. doi:10.21511/ppm.14(3-2).2016.11

http://dx.doi.org/10.21511/ppm.14(3-2).2016.11

Tuesday, 27 September 2016

"Problems and Perspectives in Management"

LLC "Consulting Publishing Company "Business Perspectives"
NUMBER OF REFERENCES

0

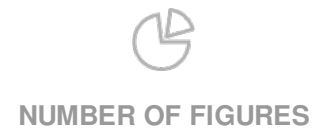

0

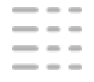

NUMBER OF TABLES

0

(C) The author(s) 2022. This publication is an open access article. 


\title{
A synthesis of changing patterns in the demographic profiles of urban street vendors in Botswana, South Africa and Zimbabwe
}

\begin{abstract}
Street vending is a phenomenon that has been in existence for hundreds of years. It has since increased owing to economic challenges experienced, especially in developing countries. This article sought to highlight changing patterns in the demographic profiles of urban street vendors in Botswana, South Africa and Zimbabwe through a desk research study. The aim was to sensitize local governments, particularly in Zimbabwe, to develop appropriate policies in line with changing patterns in the demographic profiles of urban street vendors. Findings revealed that there has been an increase in the number of single and married women in urban street vending; more young people have joined this practice and more educated people are also part of urban street vendors. The study concluded that street vending is a dynamic phenomenon with changes having been noticed in gender, marital status, age and level of education of urban street vendors. Recommendations were that local governments need to re-visit policies pertaining to planning for urban street vending in line with the changing circumstances.
\end{abstract}

Keywords: changing patterns, urban street vending, dynamic phenomenon, qualitative analysis.

JEL Classification: P25, C13.

\section{Introduction}

Street vending, a self-employment and income generating activity, is perceived by some people to be detrimental to city life, unhygienic, noisy and an obstruction to the smooth flow of commuters, pedestrians and traffic (Joseph, 2011; Adhikari, 2011). Street vendors have been blamed for crowding sidewalks, plazas and parks, coming too close on the subway, or selling too close to local businesses (Abbot and Shah, 2014). Despite these negative connotations, it is worth noting that there have been changes in the demographic profiles of urban street vendors which warrant recognition. These demographic profiles include gender, marital status, age and level of education (Research and Advocacy Unit, 2015; Tambo, 2015; Joseph, 2011, Masonganye, 2010; Njaya, 2014).

Questions that need immediate answers are 'What is street vending?' and 'Who is a street vendor?' Bromley (2001) defines street vending as the retail or wholesale trading of goods or services on streets and in other related public places such as alleyways, avenues and boulevards. Joseph (2011) views street vending from a different perspective by asserting that the phenomenon falls within the category of economic activities generally referred to as the informal sector. Although there is no universal definition of this sector, the informal sector into which street vending falls, is generally referred to as legal and ethical sound economic and commercial activities that take place outside government's licensing and regulatory framework. Therefore, street vending is unregulated trading that takes place in public spaces such as streets, sidewalks, bridges and pavements among others. This

(C) Gwendoline Vusumuzi Nani, 2016.

Gwendoline Vusumuzi Nani, Ph.D., Post-Doctoral Fellow, Department of Business Management, University of South Africa, South Africa. researcher is of the view that this definition excludes licensed urban street vendors for there are some who are licensed, especially those who operate in designated places. Njaya (2014) concurs that street vending is illegal in Harare, Zimbabwe, except in designated areas such as flea markets. According to Bhowmik and Saha (2012), a street vendor is someone who offers goods to the public at large without having a permanent built-up structure from which to sell. Njaya (2014) contends that street vendors sell everything from fresh food and medical drugs to mobile phones, mobile recharge cards, electrical gadgets, bricks and sand. For the purpose of this article, the definition of street vending incorporated all the afore-said and included regulated and unregulated street vendors providing products or services in urban areas. The study, however, excluded urban street vendors involved in criminal activities in terms of the laws of the countries under review.

\section{Background to the study}

Joseph (2011) asserts that urban planning policies and models based on the modernist thinking are geared towards creating cities and towns constituted entirely of formal settlements. Any activity regarded as informal is excluded from the urban landscape through the execution of rigid and restrictive planning and development control mechanisms. Akers (2013) concurs that even in Asia the struggle for the use of limited space is an urgent problem that urban planners and designers have to confront. The contribution by Akers (2013) shows that this challenge is not unique to Africa. Joseph (2011) further posits that, in Botswana, there were no definite statutes which addressed issues on the informal sector activities in general. Street vending and other informal sector activities in the country were and are managed using clauses found in 
legislations drawn to address different issues such as public health, food control and environmental management. Legislation appears to be one sided in its attempt to address street vending. Legislations are concerned only with penalties to those people who contravene the provisions of the clauses. These laws are insufficient in addressing the nature and manifestation of street vending activities, as they tend to be used in a process of excluding street vendors in urban areas. According to Njaya (2014), a similar scenario prevails in Zimbabwe. At metropolitan level, neoliberal by-laws and regulations continue to exclude street vendors from participating in the economic activities of the country. Njaya (2014) further opines that those bylaws had failed to adapt to the changing circumstances.

This is why the researcher felt that with the increased numbers of urban street vendors, it was important to review literature on changing patterns in urban street vending in sub-Saharan Africa with a focus on Zimbabwe. According to the Research and Advocacy Unit (2015), the growth in vendors openly engaging in street vending, contrary to the municipal laws that regulate street vending was worrying and was a symptom of an underlying economic problem. Street vendors seem to be everywhere and they do not seem to be reporting to anyone, but themselves. Even in Bulawayo, the second largest city of Zimbabwe, there has been an escalation in the number of street vendors due to the underperformance of the economy (Bhebhe, 2012; Dube, 2013; Tshili, 2014). Unfortunately, most governments resort to the use of force to try and handle the challenge of urban street vending which has not yielded any permanent solutions (Bromley, 2000; Chenga, 2013; Hansen, 2004; Ndhlovu, 2011).

Joseph (2011) argues that despite urban planning efforts to exclude street vending in Gaborone, the capital city of Botswana, these activities have over the years experienced vigorous growth and have become diverse in nature. It is now acknowledged that urban street vending in developing countries will continue to grow and, thus, require detailed understanding beyond the modernist approach. The implication from the aforesaid is that urban planners and designers did not envisage a situation where there would be competition and conflict over urban space, but street vending has brought about that reality. Therefore, urban planners and designers cannot remain rigid and hope that rigidity and inflexibility will work. Hence, the aim of this article was to conscentize government authorities that based on the information gathered; the challenge of urban street vending was actually escalating and needed to be addressed.

\section{Statement of the problem}

Street vending, which is regarded as a public nuisance by some people and has in the past been considered to be an activity for the less educated and old people, is now a source of income for the many unemployed people of various demographic profiles. Despite the abundant literature on global urban street vending, there is a dearth of studies on the synthesis of changing patterns in the demographic profiles of urban street vendors in Botswana, South Africa and Zimbabwe. Limited emphasis on this subject serves as a foundation for this study. A synthesis on the changing patterns in the demographic profiles of urban street vendors would enable policy makers to contextualize the phenomenon in its entirety and develop relevant policies to handle challenges that may arise. This study, therefore, sought to expose changing patterns in urban street vending in sub-Saharan Africa with a focus on Zimbabwe to draw attention of the Government of Zimbabwe that the challenge of urban street vending is not retreating; hence, the need to re-visit urban plans and craft policies that reflect the changing circumstances and accommodate various stakeholders. The choice of countries was motivated by the similarities in the vending patterns. For about a decade, Zimbabwe, like some other developing countries, had been going through a depressed economy that has led to massive company closures which left scores of people unemployed. The unemployed people have had to turn to urban street vending to sustain themselves (RAU, 2015; Njaya, 2014).

\section{Aim of the study}

There have been notable changes in the demographic profiles of urban street vendors in both developed and developing countries (Abbot and Shah, 2014; Joseph, 2011; RAU, 2015; Njaya, 2014). Despite research efforts on urban street vending in both developed and developing countries, the researcher did not access any study on the synthesis of changing patterns in demographic profiles of urban street vendors in subSaharan Africa, specifically Botswana, South Africa and Zimbabwe. A focus on the demographic profile of a people enables researchers to understand the people in question. Knowing what has caused changes in urban street vending, how the changes have affected stakeholders and what capabilities are required in managing these changes will enable policy makers to be proactive. Remaining in denial, being rigid and using force to mitigate the challenges will not help in any human dynamic environment.

\section{Research objective}

This article assesses the changing patterns in the demographic profiles of urban street vendors in selected Sub-Saharan African countries, with a focus on urban Zimbabwe. 


\section{Literature review}

The variables that were explored included:

- gender and marital status;

- age; and

- level of education.

Bhowmik and Saha (2012) assert that street vending had increased in major cities around the world, especially in developing nations such as Asia, Latin America and Africa. The increase was brought about by lack of gainful employment and poverty in rural areas that pushed people to migrate to cities in search of better lives. Indira (2014) concurs that there had been an increase in street vending in Asia and attributed the increase in the Asian cities to the Asian financial crisis of 1998. Akers (2013) contends that Baguio, a once ecologically affluent summer capital of Philippines was now experiencing an incessant struggle for the use of public spaces. Many workers who had lost their jobs had taken street vending as a source of livelihood. Sub-Saharan states have also witnessed increases in urban street vending and these include Botswana as reported by Jimu (2004); Nakisani and Ongori; (2013); Joseph (2013); South Africa (Willemse, 2011; Masonganye, 2010) and Zambia (Ndhlovu, 2011).

According to a study by Joseph (2011), in Gaborone, results revealed that street vending was the only alternative source of income left after failing to secure wage employment. Some of the people who were previously employed stated that they had become street vendors due to insufficient incomes, underpayment and fear of exploitation from their former employers. In Zimbabwe, early studies on vending began in the 1990s with the increase in this activity as a consequence of the Economic Structural Adjustment Program (ESAP), but as the economy declined, the informal sector became the major source of livelihood. The Central Business Districts (CBDs) are inundated with vendors stationed at street corners, traffic lights, street pavements and some in parking lots at shopping centres (RAU, 2015). Njaya (2014) confirms this assertion through a study of 145 street vendors in Harare Metropolitan City in Zimbabwe, where 88.3 percent of the vendors indicated that street vending was their sole source of income.

What is clear is that many people now depend on street vending for their livelihood. This scenario reveals a changing pattern in that street vending which falls within an informal sector is now a major employer instead of formal employment which people have always been used to. One would have expected formal employment to be more lucrative than street vending, but these changes are a pointer to the contrary. However, Joseph (2011) asserts that what has emerged from his studies on street vending in Botswana is the positive attitude on street vending that was now being shown by policymakers in Botswana. Policymakers appear to adhere to the fact that street vending activities have become an inseparable part of every city's lifestyle. According to Mitullah (2003), South Africa too had initiated processes through its Constitution that have potential for improving the business environment for micro and small businesses, especially in Durban. This scenario exemplifies another changing pattern in street vending, as some local governments have now realized that they have to incorporate street vending in their urban plans.

Zimbabwe has also reported high increases in urban street vending evidenced in the studies by Changa (2013); Njaya (2014) and Research and Advocacy Unit (RAU) (2015). However, despite the increase in the number of street vendors, policies and regulations are not appropriate for street vendors, as street vendors are hardly consulted in the development of by-laws and in the planning of the vending sites. Dasgupta cited in Joseph (2011) argues that such policies reflect the anti-vending attitude and sector activities, particularly street vending. The reality is that formal employment cannot absorb all the graduates.

\section{Research methodology}

In answering the research question, the study employed a desk approach where literature pertaining to the topic was reviewed, analyzed and synthesized. Empirical and secondary sources on three selected sub-Saharan African countries, namely Botswana, South Africa and Zimbabwe, were consulted with a bias towards Zimbabwe. The main sources of literature were journals, abstracts, newspapers and some government publications on the topic under study. Data were analyzed qualitatively. The demographic profile included gender, marital status, age and level of education.

\section{Discussion of findings}

Joseph (2011) argues that while urban planners were still firmly devoted to the notion of modernity by getting rid of street vending activities, the actual demand for vending sites was on the increase. Street vending activities are not only currently experiencing rapid growth, but they are also becoming diverse despite urban planning interventions to curtail them. It is in the context of these changing patterns that this particular study sought to assess changing patterns in the demographic profiles of urban street vendors in Sub-Saharan Africa with a focus on urban Zimbabwe.

\subsection{Changing patterns in gender and marital} status. According to Mitullah (2003), women dominated street vending although there was also a large number of men and children. Reasons for this increase in women street vendors were limited economic opportunities for women in both rural and 
urban areas, gender bias in education, and to augment husbands' incomes. Women engaged in street vending due to its flexibility, as they could easily combine street vending with other household duties such as taking care of children. Njaya (2014)'s study of street food entrepreneurs in Harare, Zimbabwe, also showed women dominating in street food vending. This was due to a number of socio-economic factors such as failure to secure formal employment due to lower education and skills levels. According to Nesvag (2000) cited by Joseph (2011), despite the enactment of repressive apartheid planning legislation to stop street vending in South African cities, there was defiance and resistance led mainly by African women who dominated in the sector and survived through it. From a gender perspective, literature indicates that street vending activities have become an important domain of women in almost all sub-Saharan African countries (Awah, 1997; Tinker, 1997; Pick, Ross and Dada, 2002).

Results of a study by Cyprian (2011) revealed that the number of single women street vendors in South Africa was lower than that of married women. Most street vendors were married and supported large families with a high percentage of women being sole bread winners. These findings could be an indication of the increased need by married women to augment their husbands' incomes and sustain themselves and their children. This changing pattern is significant, because most societies in human history have largely been patriarchal where men serve as heads of families and are considered to be breadwinners. Tasks have always been allocated on a gender basis. Gendered division of labor meant that, in general, women possessed less economic power than men (Post, Frederick and Weber, 1996). These views were also revealed by Njaya (2014) that there was perception amongst the participants in his study that in historical and cultural terms men possess certain powers which women do not have. It emerged that the participants regardless of age and/or sex symbolically defined and positioned men as ideal heads and/or breadwinners of households. Furthermore, in most patriarchal societies, the place of the woman has always been the kitchen and the major roles have largely been that of child bearing and family sustenance (Chirwa, 2008; Khumalo, 2008). However, by participating in street vending, women have financially empowered themselves, thus, reducing their economic dependence on men.

It is also a changing pattern in that men now accept women to engage in informal employment in order to supplement their incomes. Taken from a different perspective, some men have gone into street vending as a result of pressure from having working wives, while they lie idle. Although street vending impacts negatively on the man's ego, some men would rather be street vendors than to be wholly dependent on their wives. Njaya (2014) posits that traditionally street vending was associated with women, particularly housewives, but had become open to both sexes in all age groups.

Regarding the issue of single women participating in street vending, Joseph (2011)'s study on urban street vendors in Gaborone, Botswana showed that single women made up the majority of street vendors $(69.2$ percent). By comparison, single male street vendors constituted (62.5 percent). These findings are indications that gone are the days when women would solely look up to men for financial sustenance. Single women have found street vending to be another way of financially sustaining themselves.

Another notable changing pattern related to the increase in urban women street vendors is the rearing of children in the streets. Tambo (2015) asserts that female vendors have to contend with rearing their children especially babies and toddlers on the streets, because most of them cannot afford the expensive services of a maid or day care centre, while they sell their wares on the streets of most cities and towns. This sad reality of children growing up on the streets can have far-reaching social consequences, as children are vulnerable to bad weather, disease, malnutrition and even heinous occurrences as rape and physical molestation by other older children and delinquent adults. The norm has always been that women remain at home to look after their children, but because of poverty they find themselves rearing their children in the streets. In addition, bringing children to vending places can limit the performance of these urban women street vendors.

7.2. Changing patterns in the age of urban street vendors. In a study by Joseph (2011), the dominant age groups of respondents were people in the 21-40 year age bracket. According to Cyprian (2011), the age of the street vendors was between 18 and 56 years with an average of about 32 years. More than half of the street vendors were 30 years and above. There was a contrasting pattern when considering age and gender. From the survey, female street vendors were younger at all ages than men in the sample. There were 36.5 percent females and 63.5 percent males (almost double the number of men).

In a survey by RAU (2015), in the Harare Central Business District (CBD), Zimbabwe, males were more represented in the lower age groups, while women were more predominant in the older age groups, 30 years and above. Most of those that took part in the survey were in the $31-40$ age groups (39 percent) and the over 40 age group (percent). These age groups in street vending were young people who were expected to be formally employed, but again street vending 
seems to be the main employer, a sign that the economy of Zimbabwe is underperforming. According to the 2012 Census in Zimbabwe, only 30 percent of Zimbabwe's potential workforce was in full-time employment, so vending has become one of the very few avenues for earning a decent living and supporting oneself and one's family in Zimbabwe. Based on these findings, the changing pattern is that there has been a shift by youth from formal employment to street vending, an informal employment. A study by Njaya (2014) reveals that the majority of street vendors in the Harare Metropolitan Province were in the economically active groups of 21-30 and 3140 years, respectively. Njaya (2014) acknowledges that this groups' participation in the street vending sector reflected the high unemployment levels in Zimbabwe.

\subsection{Changing patterns in the level of education.} Street vending has most commonly been regarded as an economic activity for the less educated. Results of a study by Joseph (2011) shows that the majority of street vendors in Gaborone, Botswana, had low levels of formal education, evidenced by 86.3 percent who had only gone up to primary school and junior secondary school levels, respectively. The study further revealed that women had attained lower levels of education than their male counterparts. Only 11.5 percent of the female street vendors had gone to senior secondary school and tertiary level. In contrast, male street vendors who had reached the same levels of education constituted 17.8 percent. According to Cyprian (2011), in many cases, street vendors are often regarded as illiterate or lack vital educational qualifications and skills for formal employment.

In a study of Kenya, Cote D'Ivorie, Ghana, South Africa, Uganda and Zimbabwe most street vendors had primary and below levels of education (Mitullah, 2003). A few had secondary education, while very few had professional training. However, the younger street vendors tended to have higher levels of education than the older street vendors. Male street vendors seemed to have more professional training compared to women street vendors. This researcher is of the view that women had a lower level of education, because traditionally girls had less opportunities to education compared to boys.

Contrary to the aforesaid, findings by Masekesa (2014) portray a different scenario about Zimbabwe now. Some of the graduates churned out by schools, colleges and universities every year, are now selling airtime and tomatoes on the streets due to unemployment. Tambo (2015) concurs that it is estimated that more than 300000 students are churned out of schools, colleges and universities every year in Zimbabwe to join millions of the already unemployed.
These are perhaps some of the graduates that turn to street vending for a living. Njaya (2014) acknowledges that the increase in the number of university graduates in street vending was worrisome, as it signified a waste of informed human capital. The interviewed graduate respondents in his study indicated that street vending was a refuge occupation where they could earn subsistence income. Another study conducted by Nakisani and Ongori (2013) reveals that graduates were also engaged in street vending due to lack of employment opportunities after graduation. These findings portray a worrisome changing pattern regarding the educational level of street vendors where now even graduates are seeking refuge in street vending.

According to Mituallah (2003), although it has been argued that vending attracts those who have limited opportunities for obtaining formal employment and/ or prestigious business, and minimizes chances of social exclusion and marginalization; street vending is increasingly becoming an option for many citizens. It is no longer limited to lower social groups.

\section{Conclusions}

What has clearly emerged from this literature review is that street vending is on the increase and it is now the alternative to formal employment. There is no way governments can deny this fact. Based on the findings in this study, the following conclusions can be drawn:

- The number of women urban street vendors in sub-Saharan Africa has increased in recent years.

- Both married and single women have joined in urban street vending to fend for their families.

- Men are no longer the sole bread winners, as there are single women who have also joined in street vending to sustain themselves and their families.

- The number of youth engaged in urban street vending has also increased as a result of unemployment.

- Highly educated people have also joined in urban street vending.

\section{Recommendations}

Joseph (2011) argues that it is worthwhile to respond to the proliferation of street vending beyond the modernist planning approach and consider meanings people construct about their livelihoods. Masonganye (2010) asserts that while the streets might offer temporary relief to the unemployed, unless stop gap measures are taken to cater for the increased numbers of urban street vendors, streets will eventually be choked with street vendors. Based on the aforesaid, the following recommendations are made in the order of the interrogated demographic variables. 
Gender and marital status. Governments need to craft user friendly policies that will embrace the operations of street vendors, particularly the increased number of urban women street vendors who take their children along with them. Facilities should be created where women street vendors can safely vend; where young babies are not subjected to physical abuse taking into cognisance the increased number of urban women street vendors. In addition, policymakers should get onto the ground and study prevailing circumstances and come up with informed policies that suit changing times. Policymakers cannot be distanced from reality and hope to come up with policies, whilst they spend all the time in their offices. They must go out, network and dig deeper into social concerns so that they craft relevant vending policies.

Age. There is a need for governments to engage investors to revive economies to accommodate the increasing number of youth street vendors. Some of the youth might have brilliant ideas, but are not given the chance to expose their potential. Even if all unemployed youth would be encouraged to start businesses, not everyone can be an entrepreneur. Even if everyone had to be an entrepreneur who would buy from the other person? Therefore, there is a need to resuscitate formal employment that has almost collapsed to create some form of stability. What has led to these high increases in street vendors is the underperformance of economies. Governments should, therefore, come up with ways of reviving economies to absorb some of these job seekers. Youths too, irrespective of age and gender, should not continue to moan about lack of employment. They should think outside the box and see how they can legally make the street a source of employment, as the barriers to entry in street vending are minimal.

Level of education. There is a need for governments to revive the formal economy and make use of the educated human capital. The government cannot afford to heavily invest in education and at the end of the day throw the talent to waste. Alternatively, the youth can be funded and trained on how to start and run self employment projects.

In addition to the aforesaid, it would appear as if urban designers and planners never envisaged this dramatic increase in street vending. There is a need, therefore, to go back to the drawing board, re-visit their plans to accommodate the increased number of street vendors, and at the same time cater for different other street users. Gone are the days of rigid planning. There is now a need to incorporate the changing social and economic activities. Plans have to be made to cater for increased numbers of street vendors, increased number of cars, pedestrians and at the same time cater for the ambience of cities. Strategies such as pedestrianisation, reconfiguring public transportation and urban design strategies are some of the solutions that have worked in other countries and can be tried.

Local governments should capture the statistics of street vendors for planning purposes. Once they know, for example, the different age groups involved in street vending, it will be easier for the local authorities to plan for them and to account for their contribution to the economy. It is also essential that street vendors are invited to participate in important issues such as planning and management of urban development. There is a need for increased and improved communication between urban authorities, street vendors and street vendors' associations.

\section{Areas for further study}

This study focused on reviewing literature on urban street vendors in selected sub-Saharan African countries. Perhaps a literature review that focuses on changing patterns in the demographic profiles of rural street vendors in the same selected subSaharan African countries can be conducted for comparative purposes.

\section{References}

1. Abbot, T. and Shah, S. (2014). Making space for street vendors: towards equitable urban development. India: World Resources Institute.

2. Adhikari, D.B. (2011). Income Generation In Informal Sector: A Case Study Of The Street Vendors of Kathmandu Metropolitan City, Economic Journal of Development Issues, 13 \& 14 (1-2).

3. Akers, M. (2013). Urban streets struggling to survive: An urban design solution. Recent Researches in Urban Sustainability, Architecture and Structures.

4. Awuah, E. (1997). Mobilising for change: A case study of market trader activism in Ghana, Canadian Journal of African Studies, 31 (3), pp. 401-423.

5. Bhowmik, S.K. and Saha, D. (2012). Street Vending in Ten Cities in India. Tata Institute of Social Sciences for National Association of Street Vendors of India, Delhi.

6. Bromley, Ray. (2000). Street Vending and Public Policy: A Global Review, International Journal of Sociology and Social Policy, 20 (1), pp. 1-28. Available at: http://www.emeraldinsight.com/journalshtm?articleid=850310. Accessed on January 4, 2016.

7. Chenga, N. (2013). Informal Sector: The major challenge, The Financial Gazette. Available at: www.financialgazette. Accessed on 07 January, 2016.

8. Chirwa, E.W. (2008). Effects of Gender on the performance of micro and small enterprises in Malawi, Development of Southern Africa, 25 (3), pp. 347-361. 
9. Cyprian, L.Y. (2011), Migratory trajectories among street vendors in urban South Africa. A thesis submitted in fulfilment of the requirements for the award of an MPhil Degree in Population Studies. University of the Western Cape.

10. Dube, Musa. (2013). Zimbabwe: BCC gives up on illegal vendors, The Standard. Available at: www.thestandard.co.zw/2013/.../bulawayo-city-council-gives-illegal-vendors/. Accessed on January 20, 2016.

11. Gcumeni, F. and Reeler, T. (2015). Vending in the streets of Harare. Research and Advocacy Unit.

12. Hasan, M. and Alam, J. (2015) Street Garment Vendors' Contribution to the Economy and Local Community: An Empirical Study to the Street Garments Vendors in Dhaka City, Bangladesh, International Journal of Business Research, 5 (2), pp. 129-139.

13. Hansen, K.T. (2010). Changing Youth Dynamics in Lusaka's Informal Economy in the Context of Economic Liberalisation, African Studies Quarterly, 2 (2 \& 3).

14. Indira, D. (2014). A study of street vending across the globe, International Journal of Advanced Research in Computer Science and Software Engineering, 4 (9).

15. Jimu, I.M. (2004). An exploration of street vending's contribution towards Botswana's vision of prosperity for all by 2016, Pula: Botswana Journal of African Studies, 18 (1).

16. Joseph, M.C. (2003). Urban planning aspects of street vending in Gaborone city, Botswana. (MPhil Thesis). Department of Architecture and Planning. University of Botswana.

17. Joseph, M.C. (2011). Beyond modernist planning: Understanding urban street vending in Botswana. Paper presented at the International RC 21 conference 2011. Amsterdam, 7-9 July 2011.

18. Khumalo, V. (2006). Women Entrepreneurs in Small-Medium and Micro Enterprises. A case study in Swaziland. Bloemfontein: University of the Free State.

19. Masekesa, C. (2014). Street vending: The only option for Zimbabwe's graduates. Available at: www.thestandard.co.zw. Accessed on 14 March 2016.

20. Masonganye, M. (2010). Street trading in Tshwane Metropolitan Municipality: Realities and Challenges. Available at: www.urbanlandmark.org.za/.../report_street_trading_jan2010pdf.

21. Mitullah, W.V. (2003). Street Vending In African Cities: A Synthesis Of Empirical Findings From Kenya, CoteD'Ivore, Ghana, Zimbabwe, Uganda and South Africa. Background paper for the 2005 World Development Report_WIEGO Urban Policies Programme Director.

22. Nakisani, C.C. and Ongori, H. (2013). An assessment of challenges faced by Micro enterprises in Botswana: A case of street food vendors in Gaborone, International Journal of Learning and Development, 3 (5).

23. Ndhlovu, P.K. (2011). Street Vending in Zambia: A case of Lusaka District. A Research Paper submitted in partial fulfilment of the requirements of Master of Arts Degree in Development Studies. International Institute of Social Studies. The Hague. Netherlands.

24. Nesvag, S.I. (2000). Street trading from apartheid to post-apartheid: More birds in the cornfield, International Journal of Sociology and Social Policy, 20 (3-4), pp. 34-64.

25. Njaya, T. (2014). Nature, Operations and socio-economic features of street food entrepreneurs of Harare, Zimbabwe, IOSR Journal of Humanities and Social Sciences, 19 (4), pp. 49-58.

26. Njaya, T. (2014). Challenges of Negotiating Sectoral Governance of Street Vending Sector In Harare Metropolitan, Zimbabwe, Asian Journal of Economic Modelling, 2 (2), pp. 69-84.

27. Pick, W.M., Ross, M.H. and Dada, Y. (2002). The reproductive and occupational health of women street vendors in Johannesburg, South Africa, Social Science and Medicine, 54, pp. 193-204.

28. Post, J., Frederivck, W. \& Weber, J. (1996). Business and Society Corporate Strategy, Public Policy, Ethics. $8^{\text {th }}$ edition. London: McGraw Hill International.

29. Research and Advocacy Unit (RAU). (2015). Vending in the streets of Harare. Available a: http://researchandadvocacyunit.org/system/files/Vendors\%20Report.pdf.

30. Tambo, B. (2015). Vending in Zimbabwe: new reality or passiong phase? Sunday News June 28, 2015.

31. Tinker, I. (1997). Street Foods: Urban Food Employment in Developing Countries. New York. Oxford University Press.

32. Tshili, Nqobile. (2014). City Council in street vending poser, The Chronicle. Available at: http://www.chronicle.co.zw. Accessed on January 30, 2014.

33. Walsh, J. (2010). Economic Impact of Street Vending in Bangkok and Kunming: A Comparative study. Paper presented at International Colloquium on Business and management, Bangkok (January 26-28, 2010).

34. Willemse, L. (2011). Opportunities and constraints facing informal street traders: Evidence from 4 South African Cities, Town and Regional Planning, 59, pp. 7-15.

35. ZIMSTAT (Zimbabwe National Statistics Agency). (2012). Census 2012 National Report. Harare: ZIMSTAT. 